\title{
Problems of Shariah Governance Framework and Different Bodies: An Empirical Investigation of Islamic Banks in Bangladesh*
}

\author{
Md. Kausar ALAM ${ }^{* *}$, Hasri MUSTAFA***, Md. Salah UDDIN****; Md. Jahirul ISLAM ${ }^{* * * * * *}$, \\ Marjea Jannat MOHUA******, Md. Farjin HASSAN ${ }^{* * * * * * * *}$
}

Received: December 12, 2019 Revised: February 06, 2020 Accepted: February 07, 2020.

\begin{abstract}
The study aims to explore the problems of the existing Shariah Governance Framework (SGF) and its concerned authorities in the context of Bangladesh. Thus, according to responses from 17 respondents, this study outlines that Bangladesh has an absence of a shortage of experts, experienced, knowledgeable, and qualified Shariah people at all levels (i.e., the central bank, Islamic banks, Shariah Supervisory Boards (SSBs), and regulators). Therefore, Bangladesh does not have a separate Islamic banking act, Shariah audit firm, Shariah index institutions, and comprehensive SGF. The existing guideline has a limitation concerning its comprehensiveness, accountability, responsibility, and structure of SSBs. Islamic banks do not follow the instruction of the central bank in the formation of SSBs. As a result, there is an absence of competent and qualified SSB, which also results in the functions of Shariah departments as well as Shariah applications. Usually, the Board of Directors (BOD), management, executives, customers, and the public also have the conceptual gap about Islamic banks, SGF, and banking system compared to the regular prayers, faith, and belief. Concisely, Bangladesh requisites a comprehensive SGF, Islamic banking act, a standard accounting system, and a robust Shariah audit system for the overall development of Islamic banks and SGF.
\end{abstract}

Keywords: Shariah Governance, Shariah Governance Mechanisms, Problems, Islamic Banks, Bangladesh.

JEL Classification: G18; G21; G28; G38.

\section{Introduction}

\footnotetext{
*The authors gratefully acknowledge the financial support of the Research University Grant Scheme of Unievrsiti Putra Malaysia, vote number, 13001.

${ }^{* *}$ First Author. PhD Candidate, Faculty of Economics and Management, Universiti Putra Malaysia, Selangor, Malaysia Email: kausarflorence@gmail.com

${ }^{* * *}$ Corresponding Author. Associate Professor, Department of Accounting and Finance, Faculty of Economics and Management, Universiti Putra Malaysia (UPM), Malaysia. [Postal Address: Room\# E205, Faculty of Economics and Management, Universiti Putra Malaysia (UPM), Serdang, Selangor, 43400, Malaysia] Email: hasyie@upm.edu.my

${ }^{* * * \star}$ Assistant Professor, Department of Accounting and Information Systems, Faculty of Business Studies, Jagannath University, Dhaka, Bangladesh. Email: salahuddin@ais.jnu.ac.bd

${ }^{* * * * *} \mathrm{PhD}$ Student, Faculty of Modern Language and Communication, Universiti Putra Malaysia, Selangor, Malaysia. Email: jahirupm17@gmail.com

*****PhD Student, Putra Business School, Universiti Putra Malaysia, Selangor, Malaysia. Email: marjeanayah@yahoo.com ${ }^{* * * * * *}$ MS Student, Putra Business School, Universiti Putra Malaysia, Selangor, Malaysia. Email: farjinhassan@gmail.com
}

Bangladesh experienced with Islamic banking in 1983 by the establishment of the 'Islami Bank Bangladesh Limited' as a first Southeast Asian county (Hassan, Ullah, \& Khanam, 2017). Accordingly, growth and progress are enhanced gradually. As a result, Bangladesh has proven as an affected country in the global financial crisis of 2008 (Wasiuzzaman \& Gunasegavan, 2013). Now, Bangladesh 8 full-fledged Islamic banks, along with 19 Islamic banking branches, and 35 Islamic banking windows (Bangladesh Bank, 2019). All of the conventional banks in Bangladesh are trying to operate Islamic banking activities due to the success and public acceptance of Islamic banks as well as fascinating Muslims people (Rahman, 2014). Though Islamic banks have explored and acquired $23.66 \%$ of total deposits and $24.16 \%$ of total investment in Bangladesh (Bangladesh Bank, 2019), still they are facing problems regarding due to the absence of a proper Corporate

() Copyright: The Author(s)

This is an Open Access article distributed under the terms of the Creative Commons Attribution NonCommercial License (https://creativecommons.org/licenses/by-nc/4.0/) which permits unrestricted noncommercial use, distribution, and reproduction in any medium, provided the original work is properly cited. 
Governance structure and full-fledged legal framework in functioning their functions which hinder the growth of this industry (Ahmad, Rashid, \& Shahed, 2014; Perves, 2015).

In 2009, the central of Bangladesh (Bangladesh Bank) has outlined a guideline for the Islamic banks though it has limitations. Researchers have described that still Bangladesh is facing in the absence of a complete supervisory and regulatory Shariah Governance Framework (SGF) to monitor, guide and supervise the overall Islamic banking business (Alam, Rahman, Mustafa, Shah, \& Hossain, 2019a; Perves, 2015; Ullah, 2014; Ahmad et al., 2014). Besides, the central bank is mainly focusing on conventional banks; thus, there are very fewer initiatives have taken by itself (Alam et al., 2019a). Again, the current rules and regulations of the central bank can monitor the functions and minimize the possible risks of the Islamic banks but incompetent to maintain the institutional image of Islamic banks, the faith of the customers, investors, and people and lessen Shariah risk. Additionally, the absence of a comprehensive Shariah Governance (SG) system generates regulatory gaps, and confusions among the traditional bankers, business people, customers, governments and industrialists concerning Islamic banks Shariah compliance (Abdullah \& Rahman, 2017; Ahmad et al., 2014; Sarker, 1998).

Also, numerous researchers highlight the practices of SG, problems, and challenges of SG as well as legal and regulatory issues, a Centralized Shariah Supervisory Board (CSSB) formation and legalization of existing Central Shariah Board for Islamic Banks of Bangladesh (CSBIB), Shariah compliance and disclosure of Islamic banks in Bangladesh and SG practices and regulatory problems of Islamic insurance companies in the context of Bangladesh (Alam et al., 2020a; 2019a,b; Ullah \& Khanam, 2018; Ullah, Khanam, \& Tasnim, 2018; Hassan et al., 2017; Perves, 2015; Ullah, 2014; Ahmad et al., 2014; Ahmed \& Khatun, 2013). But the problems of SG practices and concerned bodies of the Islamic bank in Bangladesh were unexplored from the empirical point of view, which motivates the authors to conduct this research. The issues of the existing SGF and concerned authorities will be helpful for the regulators and Islamic banks to improve their current practices and solve the problems accordingly.

According to the responses of the 17 semi-structured interviews, the study outlines that Bangladesh has an absence of a complete SGF, a Centralized Shariah Supervisory Board (CSSB), an accounting and audit system, Islamic Chartered Accountant firms, and Shariah audit index in its overall supervision of the Islamic banks. Besides, Islamic banks have formulated their SGF. Thus, they have similar governance but diverse practices. The executive officers of the Islamic banks are involved with corruption and unfair functions though there are no initiatives from the management. All of the Islamic banks are violating Shariah principles more or less in their banking functions as a result of high profit-making intention, low accountability, Board of Directors (BOD) pressures, and market demand. Again, Islamic banks do not follow the existing guideline of the central bank in formulating their Shariah Supervisory Boards (SSBs).

Concerning the reporting and disclosure, Islamic banks do not disclose the Shariah non-compliance amount and their compliance procedures, which create confusion about their overall Shariah compliance process and quality. The BOD members, SSBs, managements, general people, customers, bankers, and executives of Islamic banks have a theoretical gap concerning Islamic banks, their business, and SG procedures. Management is not sincere and proactive in applying SG guidelines and Islamic principles (Sarker, 2005; Ahmad et al., 2014). Islamic banks are not concerned about the particular Shariah rating agencies though it will enhance their institutional image, public trust, and business profit. In preparing a comprehensive SGF and separate Islamic banking act, Bangladesh has an absence of qualified, knowledgeable, and experienced peoples, regulators, bankers, policymakers, SSBs, and Shariah officers.

The study has contributed to the contemporary literature of SG, regulators, and Islamic banks in Bangladesh. At first, this study illustrates the research of SG concerning the Islamic banks of Bangladesh by outlining the problems of existing practices and concerned authorities. Second, the regulators are to benefit from the findings of this study, which require implementation for the development of current practices. Third, Islamic banks will be able to solve the problems of the different bodies related to their particular SG structure and practices, which will enhance their institutional image, performance, and Shariah compliance quality. Fourth, the study will be beneficial for the SSBs to improve the quality for themselves and Shariah officers of their particular bank. The findings of the study indicate that Bangladesh should develop a comprehensive SGF for the development of the Islamic banks and their governance systems.

The paper is structured as follows: Section 2 delivers the literature review along with theoretical support. Section 3 provides data collection and analysis processes. Section 4 describes the empirical evidence, and finally, part 5 illustrates the concluding remarks.

\section{Literature Review}

The growth of Islamic banking and finance developed in 1970 in the global world. For monitoring the Islamic banking functions, countries have applied the convention 
law and rules due to the absence of proper guidelines. After that, several initiatives have been taken by countries to develop the guidelines, standards, and accounting policies for Islamic banking and finance. Thus, the Accounting and Auditing Organization for Islamic Financial Institutions (AAOIFI), the Islamic Financial Services Board (IFSB), and the International Islamic Rating Agency (IIRA) have formed to acclimate conventional standards and promote synchronization of practices for Islamic Financial Institutions (IFIs).

From the political and financial viewpoints, Warde (2013) divided the past of modern Islamic finance into three stages: the first era from 1975 to 1991, distinguished by renewed interest in Islamic economics and finance thought; the second era 1991-2001, marked by experiments and setbacks in turning theory of Islamic finance into practice; and lastly, after 2001, signified by a boom, increased fluency in Islamic finance across entire countries, and more international financial institutions providing Islamic financial services. There are three models in Islamic Banking and Finance (IBF). The first is a whole IBF structure (for example, Iran, Sudan, and Pakistan). Secondly, the dual banking system based on bank-level fatwa and a "bottom-up" approach for the employment of SSBs. Finally, a dual banking system determined by national developmental goals and a "topdown" fatwa approach (such as in Malaysia). The majority of IFIs, including Bangladesh, follow the "bottom-up" approach. In this model, the SSB is selected and rewarded by the particular BOD, casting doubt on their independence. This practice can result in variances in fatwas both at national and international levels.

Additionally, in this model, the Shariah professional sit in multiple SSBs, which could result in conflicts of interest. As a result, the complete legitimacy of these SSSs and internal Shariah audit units is questionable. Scholars supported the move toward CSSB and argued for the significance of international standards for Shariah compliance (Wilson, 2010; Chapra \& Ahmed, 2002). The nationwide "top-down" approach has been followed in Malaysia for decades and applied in Dubai, Pakistan, Indonesia, Oman, and Nigeria, where SSBs are nationwide. However, this approach also positions questions about political influence on the SSBs from governments. Recently, the Islamic Development Bank (IDB) suggested the formation of a global SSB, which would provide better convergence in the Islamic finance industry.

Islamic banks perform operations according to the guidelines of Shariah, considered as the foundation for guiding all services (Ahmad, 2000; Akbar, Zulfiqar Ali Shah, \& Kalmadi, 2012; Khan \& Mirakhor, 1986; Siddiqi, 1983; Siddiqui, 2001). "The adoption of Shariah leads Islamic banks to focus more on ethical and moral values in their banking industry rather than credit value" (Hamdi \& Zarai, 2012).

Shariah compliance is considered as the most critical factor to introduce products of the banks by ensuring the trustworthiness of the banks and increasing the confidence of the bank owners and other stakeholders (Ahmad \& Haron, 2002; Archer \& Karim, 2002; Ghayad, 2008; Laldin, 2008; Naser, Jamal, \& Al-Khatib, 1999; Rammal, 2006; Rashid, Hassan, \& Ahmad, 2009; Tomkins \& Karim, 1987). Besides, the studies of Imam and Kpodar (2013), Jalil and Rahman (2010) and Rahman (2007) noted that the removal of all types of injustice and malice caused by Riba (interest) is possible by developing Islamic financial system, that is, complying with Shariah tenets in banking operations. Also, Dawood (2008) emphasized initiating more and more Shariah-compliant businesses for meeting the growing demands of Muslims for Islamic products and services. Furthermore, Shariah compliance is also an urgent necessity for businesses to purify their incomes and expenses.

SG is a complete system that outlines how IFIs follow the Shariah principles in conducting their business functions (Ginena \& Hamid, 2015). IFSB-9 (2009) illustrated SG systems as "a set of structural procedures where IFIs assure the Shariah compliance throughout its operational activities". The SGF provides a comprehensive guideline for BOD, SSB, Shariah auditors, internal and external Shariah audit and review unit, the appointment of criteria of SSB, management obligation in employing SGF, Shariah compliance, and Shariah review to conduct the Islamic banking functions and to develop a stronger and more trustworthy industry. For doing these functions, IFIs essential comprehensive Shariah audit functions and regulations to ensure and monitoring Shariah principles on a pre and post functional basis.

As an internal mechanism of SG and an independent body within the Islamic bank, the Shariah audit should be ensured by the SSB (Garas \& Pierce, 2010). This SSB considered an essential Shariah strategic body of the Islamic banks under the governance (Grais \& Pelligrini, 2006). SSB ensures Shariah principles in the overall transactions to fulfill the demand of the customers of the Islamic bank (Abu-Tapanjeh, 2009). They review and supervise the complete banking functions, develop policies, and certify the banking products as per Shariah law. Annually, they outline a Shariah report on the yearly services done by the Islamic bank by describing the Shariah compliance quality and evaluating "management performance and the distribution of the net income between the shareholders and investment accounts holders" (Garas \& Pierce, 2010). 


\section{Methodology and Data collection}

For this study, we applied qualitative research as it ensures the provision of understanding about how and why things occur (Cooper \& Schindler, 2011). It comprises "an array of interpretive techniques which seek to describe, decode, translate, and otherwise come to terms with the meaning, not the frequency, of certain more or less naturally occurring phenomena in the social world" (Cooper \& Schindler, 2011).

Prioritizing Bangladesh, as a case research, this research aims to explore the problems of SG practices and concerned authorities related to the governance system. The crucial features of the case study are its attention on 'how' and 'why' questions (Myers, 2009), and therefore, it is fit for descriptive and exploratory readings (Mouton, 2001). A case study emphasizes the vital process, the behavior of the individuals or group of people in an organizational setting, and the system of actions in which the reaction happens (Stake, 2005). Another reason for a preferred case study is that the researchers cannot deploy real behavioral responses (Yin, 2003). Therefore, the interview questions were to the regulators, SSB members, field experts, and Shariah department executives of the Islamic banks regarding the $\mathrm{SG}$, where there is no chance of influence by the researcher towards them. A similar approach has been applied in the previous research for overall research methodology in outlining the legalization process of central regulatory authority, the influence of BOD and management in SG guidelines of Islamic banks in Bangladesh and reasons behind the absence of a comprehensive SG of Islamic banks (Alam et al., 2020a, b).

The semi-structured interview was selected to extend more data connected to the study and to have a more comprehensive understanding of the practical aspects of the subject matter. Semi-structured interview denotes that "the interviewer poses a few predetermined questions but has considerable flexibility concerning follow-up questions" (Dane, 1990, p.129). This interview method gained the attention of researchers because of its flexibility, which permits the investigators to explore more thoroughly the views of respondents, which may result in more and wideranging details of the entire assembly of answers (Dane, 1990).

Besides, this technique provides the opportunity for the respondents to outline their ideas according to their knowledge and practical experiences (Saunders, Lewis, \& Thornhill, 2007). The indifference with other sorts, the semi-structured interview method, is capable of aiding the ability to express more profound perceptive evidence based on the prepared questions of the phenomenon (Berg \& Lune, 2007). This technique is vital to clarifying and understanding the events, designs, and procedures of behavior to deliver a more rigorous image of respondents' positions (Bryman \& Bell, 2003).

A face-to-face interview technique was applied to collect data as it may comfort the process of achieving a clear understanding of the research topic. Interviewing on a faceto-face basis stimulates the depth of replies from the participants. This procedure helps the respondents to understand the questions more clearly (Sekaran \& Bougie, 2010). A face-to-face interview protects the individuality of the respondents in outlining their views, which is a vastly valued quality in a data collection process (Kvale, 1996; Gillham, 2000; Sekaran, 2003). Therefore, the respondents are directly related to policymaking and functioning of the SGF in the Islamic banks, as well as having the vast knowledge, familiarity, and practical experiences about the Islamic banking activities and its SG. The researchers conducted interviews on 17 respondents who have a direct link with the central bank, Islamic banks, SSB, Shariah department, and SG functioning by using a face-to-face semi-structured interview question. The respondents gave a symbolic identity for protecting their confidentiality, which is 'RA' (Regulatory Aspects) from the central bank, 'SP' (Shariah Practitioners) from the Islamic banks, and lastly 'E' (Experts) who are related to the industry and research in this field.

The NVivo software package is suitable for analyzing massive textual data in qualitative research, as it permits more in-depth analysis (Patton, 2002; Gibbs, 2002). NVivo software is the technique for making code, categorization, and themes (Strauss, 1987; Joffe \& Yardley, 2004) as it allows the researcher green data management and analysis tools rather than the paper and pencil technique. Initially, the researcher made open code to identify the fruitful outcomes from the gathered data and proceed with the development of categories and themes. The findings of the analysis are in the section below.

\section{Findings and Discussions}

The two sub-research questions are to detect the problems of current SG practices and its mechanisms. They are (a) what are the issues and obstacles you are facing in the current practice of SGF in Bangladesh, and how can these problems be resolved?; and (b) How do you explain the issues of different bodies (SSB, BOD, and Central Bank) in monitoring the SGF and Shariah compliance? Based on the responses of the respondents concerning these questions, this study has outlined six categories and provides some recommendations to solve the problems as well as highlights the importance of the Centralized Shariah Governance Framework (CSGF). Thus, the research questions regarding the difficulties of current SG 
practices and the problems faced by the numerous parties associated with the SGF are in Figure 1.

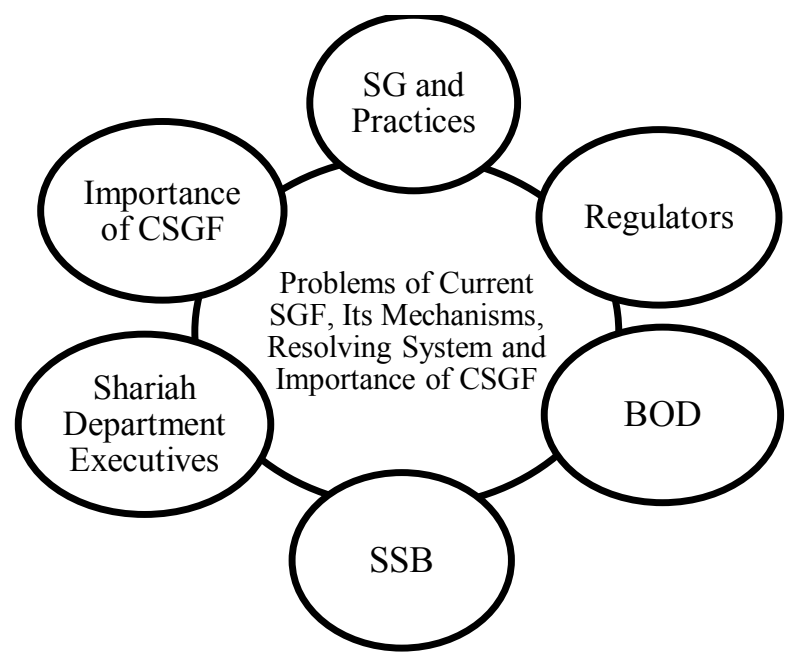

Figure 1: Theme of problems of SGF and its mechanisms

This part highlights the absence of comprehensive SGF, a proper Shariah audit system, CSSB, and the Shariah audit index in Bangladesh. Sometimes, the Shariah executives are not to conduct an audit in all investments and clients.

In Bangladesh, there is an absence of a proper SG system, a standard accounting system, and, finally, a standard audit system. Due to the lack of CSGF, every bank has formulated and followed its own SGF, which does not have any standard, and the system is homogeneous. Therefore, the monitoring of the central bank is relatively low.

"There is no standard accounting system, there is no standard governing system, and there is no standard auditing system. Every bank is following its approach, in what they are doing. There is no standard uniform system". [E\#3] ".... a lack of monitoring from the central bank. [SP\#5]

Conversely, one of the respondents highlights Bangladesh has a particular guideline that is not uniform amongst Islamic banks. In accomplishing the functions of $\mathrm{SG}$, there is no Shariah audit firm, Shariah audit guidelines, and CSSB for Shariah compliance. Also, there are no standard obligatory guidelines and requirements from the central bank for Shariah compliance, and Islamic banks are not bound to comply with 100 percent Shariah compliance due to the lapses in the central bank. In this case, Ahmad and Hassan (2007) opine that the most crucial issue is the absence of a well-defined regulatory and supervisory framework for the effective functioning of the Islamic banks in accomplishing their functions in Bangladesh.
"I think there is a standard, but this is not uniform among the banks." [E\#3] "There is no Shariah audit firm, there are no Shariah guidelines, Shariah audit guidelines, there is no centralized authorized body for the Shariah compliance from the Bangladesh Bank, and banks do not need to comply the 100 percent Shariah compliance, another thing depends on their willingness because there is no strict direction from the Bangladesh Bank to maintain the SG so far I know". [E\#4]

Therefore, Islamic banks are unable to thoroughly check all types of investment and policies because of the shortage of Shariah executives. Besides, the Shariah officers cannot understand the correct Islamic banking practices due to the profit motive of the BOD, banks, and management. Thus, it is crucial to formulate different Shariah audit manual and uniform software to record Shariah due to their current absence in the practices.

Moreover, there is a dispute mindset among the Shariah officers and branch officers concerning Shariah audit and Shariah non-compliance, even though the branch should welcome the Shariah auditors to discover the mistakes and solve the issues. However, the branch manager and executives have a different perception. To them, Shariah auditors come to minimize the profit when default income becomes uncovered. This practice considered as Shariah violations, which lead to negative marking in the Annual Confidential Report (ACR) and thus impacting the promotion system. Hence, this is the most negative perception that needs to be rectified and resolved. The evidential literature shows that there is a misunderstanding among Shariah officials and banks' executives (Ullah, 2014).

"We cannot do this comprehensively all the deals or investments due to the lack of sufficient executives." [SP\#3] "Secondly, we cannot properly practice Islamic banking or Islamic ideology because of the intention of more profit, and that is why there are many problems." [SP\#6] "Fourth, it should be determined which method should be followed in Shariah audit and which software is needed. In this regard, we need software, a proper mindset of all which is lacking in Islamic banks. Here we see that the Shariah secretariat and branch have a hostile mentality between them regarding environment and relation". [SP\#7]

Bangladesh does not provide separate banking law and CSSB in the central bank to monitor Islamic banks. If a different Islamic banking act and rules are drawn, Islamic banks will be able to solve the problems effectively. The absence of CSSB is hampering SG functions.

"So, I think another aspect we already discussed there is 
no separate law." [E\#3] "If there is an Islamic banking act and consequently there will be Islamic banking rules there against then." [E\#5]

The existing guidelines also have limitations regarding SSB selection, appointment, and composition criteria. The central bank does not limit the number of positions held by SSB members in terms of services. The respondents also opine this is due to the absence of qualified and experienced Shariah personnel. Previous studies also confirm Bangladesh has a shortage of Shariah knowledgeable personnel (Malik, Malik, \& Mustafa, 2011; Hassan et al., 2017). The researcher also observes and supports the same phenomenon in Bangladesh. They are far behind the global knowledge, standard, practices which are very old, and archive. Besides, SSB members of Islamic banks in Bangladesh have limitations concerning Islamic banking and finance, and some of them have language barriers, too, especially the English language (Rahman, 2014; Hassan et al., 2017).

"What should be the minimum experience and wheatear one can act as a member for other company, whether there is any bar for a Shariah member to be an employee of that organization or the director of that organization. So, there are conflicting interests". [E\#2] "We don't have the Shariah professionals. You know that the Shariah educated people are still not of global standard. If you need to run an Islamic bank, you have to have global knowledge, global standards. And our SSB still very archive, very very old standard". [RA\#1]

Therefore, Islamic banks are not concern about the Shariah principles. All the banks are violating Shariah principles due to internal and external reasons. The issues are due to the intention of profit-making, lack of accountability, pressure by BOD members, and market demand. The study of Ullah (2014) explains the violation of Shariah principles are avoidable if due attention is given to ensure that the management at the branch level deals with the phenomena effectively. Islamic banks are more successful in the banking business due to customer demand, market growth, and religious influence; however, in reality, they are not practicing the proper Islamic banking based on Shariah rules and principles.

"I can say here there in less implication of Shariah principles." [SP\#6] "There is no bank where the $S G$ is completely and freely implemented. Due to some internal reasons, it is also hampered as well by external reasons". [SP\#7] "So we see the quality Islamic banks but in true sense is not the same Islamic bank as was envision but maybe they have adjusted with the time." [RA\#1] "They think that it is not an Islamic bank; they blame that it is worse than the interest-based banks because they do business by the name of Islam." [SP\#7]

Other important issues in the current SG practices are the disclosure of Shariah non-compliance amount and the complying system. The questions of how and in which way are Islamic banks complying with Shariah principles and how many areas covered in their audit, and compliance review process require investigation. More interestingly, do SSB members know everything about the banks? Or, how much they know about Shariah principles and guidelines in the applications, audit, and compliance process?

"But in the present contest, never a bank reports the noncompliance to the regulators." [E\#1] "But the problem is complying, what extent they are complying the Shariah rules." [E\#3] "What are they thinking? Is there anything they are doing knowingly or unknowingly? They should know everything”. [E\#3]

However, the respondents (E\#2; SP\#8) point out the non-qualified and unexperienced SSB also lack the knowledge concerning Islamic finance, and they do not have the opportunity to learn. Moreover, some of them do not know Arabic and English. In this case, the observation also denotes the language barrier among SSB members in terms of having a good command of the English language to understand the global standards. Besides, in Bangladesh, Shariah learning processes are done in either Urdu, Farsi, or Arabic. Thus, they do not have the proper in-depth knowledge in Arabic either. Consequently, this language barrier creates a knowledge gap among SSB members.

"So, the challenges are that there is little scope or little opportunities in Bangladesh that the Shariah people know everything about Islamic finance; they do not know." [E\#2] "So far the Shariah people in Bangladesh, it is not necessarily they do have an understanding or that mastery over Arabic as well as in English. They have learned these Shariah tenants either in Urdu or in Farsi or sometimes in Arabic. So, this is one language barrier and is one important factor that is hindering the knowledge of our Shariah peoples". [E\#2]

Also, there are no professional degrees or courses on Islamic banking and finance in Bangladesh, like Malaysia. As a result, SSB members cannot provide the expected services and develop Shariah products.

"There is no course in our public university like Malaysia." [E\#3] 
The overall problems of Shariah compliance are caused by the knowledge gap, lack of training among the executives, and finally, the lack of knowledge among customers regarding Islamic banking procedures although, they favor and demand the banks to practice Islamic banking.

"Number one problem is knowledge." [SP\#5] "The training or education is not at the expected level. They need more Shariah knowledge". [SP\#5] "Number three is in some cases our clients need education on Islamic banking. They need, feel for their work, sentiment or beliefs, religious beliefs that are required Islamic banking, but they are not knowledgeable". [SP\#5]

Figure 2 provided by one of the respondents outlines Shariah banks and framework and an overview of the modes or operation or Islamic banking.

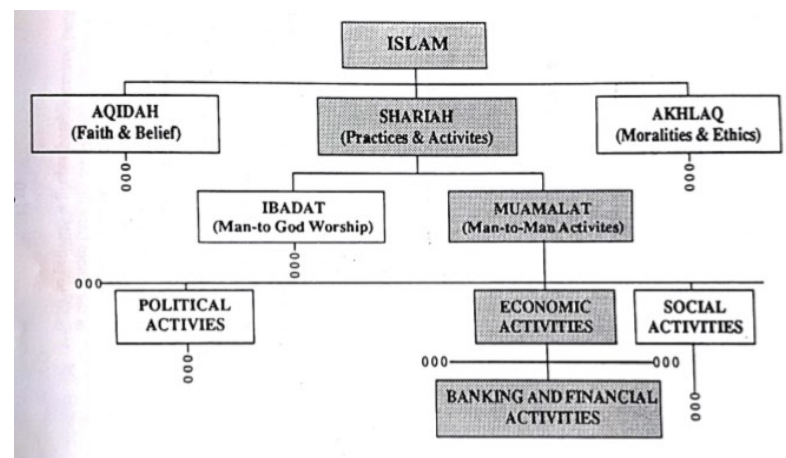

Figure 2: Islam, Shariah, Muamalat, banking and finance

Figure 2 indicates the public and the customers, as well as Islamic bankers, management, executives, officers, and BOD, have a conceptual gap regarding Islamic banks, banking business, and SG. Islamic finance compliance cannot be comparable to regular Islamic prayers and Aqidah (faith and belief). He also emphasizes Islamic banks, and the concerned authorities should take proper initiatives, for example, advertisement, customer care service, discussions, seminars, and symposiums to solve these problems.

BOD also has a conceptual gap concerning SG principles. The respondent points out BOD thinks if SSB certifies certain products, based on fatwas, they become halal, or Shariah approved. Everything depends on SSB certifications. Moreover, in assisting the Shariah secretariat, the management sometimes recruits general executives who do not have any Shariah knowledge. Occasionally, the expert executives of the Shariah secretariat can move to the branches.
"BOD of some Islamic banks also thinks, or their concept is that Shariah rules depend on the opinion of the SSB. If they are brave, then it will be halal in Islam or halal in Shariah". [SP\#7] "Shariah secretariat executives should be experts in both fields, i.e., Shariah and banking. But we notice that frequently in this place the general banking people are provided here, and the experts are transferred in the branches". [SP\#7]

Previously, Islamic banks focus on Shariah knowledgeable candidates in recruiting, but currently, they only concentrate on candidates with a general background. As a result, there is a lack of Shariah implementations and compliance.

"Islamic banks are facing problems, mostly in employee training. There is a lack of employee training and currently in the recruitment process. All the Islamic banks are prioritizing the general perspective people than the Shariah knowledgeable and banking knowing people. As a result, the activities of Islamic banking are hampering". [SP\#7]

However, in accomplishing Shariah audit functions, Shariah departments have very few executives than the required workforce. For example, the respondent opines the bank requires 100 personnel but has 10-12 staff only. Thus, it is quite impossible to perform full Shariah audit functions.

Further, without adequate Shariah executives, it is not possible to explore accurate Shariah compliance. In supporting this, Ullah (2014) also explains the shortage of Shariah executives is responsible for inadequate inspections. Moreover, the researcher also observes the same viewpoint from the executives. There are very few Shariah executives in Islamic banks.

"...there we need say, 100 people; they provide 10/12". [SP\#7] "This is must, and we have to lack the Shariahcompliant people." [SP\#9] "They need the required workforce, and have sufficient human resources. As a result, the proper Shariah audit is not well performed properly". [SP\#7]

Besides, there is an absence of cooperation and fatwas sharing among Islamic banks due to business and policy issues.

"Also, in some cases, there is a lack of cooperation among Islamic banks." [E\#3] "In this case, all banks will not share their fatwas due to their respective policy issue." [SP\#8] 
However, in the current practice, management is not strict and not sincere to implement Shariah principles and ensure Shariah compliance. About this view, previous literature explains BOD and management are not proactive in obeying and implementing Shariah principles (Sarker, 2005; Ahmad et al., 2014). Besides, the study finds the management and BOD want Shariah compliance on paper as documents, instead of the actual implementations or practices. Thus, Islamic banks comply with Shariah principles partly because of the competition in the banking sector, which hinders the system from achieving the desired outcomes (Mamun, 2011). More interestingly, sometimes, issues provided by the management are nonsignificant and not even discuss by SSBs.

"The authority must be fully committed; they must make a decision; they will run their bank based on the Islamic Shariah." [E\#3] "Management is not so determined to do it. They are careless". [SP\#1] "In the current practice, the problems are that we want Shariah, but in terms of feeling some are not. In the managerial body, they are in relaxation to follow the Islamic principles". [SP\#2] "If the management gives any agenda, then the SSB does not feel any importance to discuss the matter." [SP\#6]

Since the central bank controls Islamic banks, directives from the central bank are complied with, although they are non-compliance to Shariah guidelines and not profitable nor beneficial to the Islamic banks. These include school banking, Corporate Social Responsibility (CSR) activities, and other non-profitable functions. The central bank is not concerned with Shariah guidelines, and Islamic banks, on the other hand, are accountable to the central bank, forgetting the fact accountability of Shariah rules and guidelines is meant to be to Almighty Allah.

"The Islamic banks also obey the different guidelines and regulations of Bangladesh Bank, which is not profitable, for example, "school banking" CSR activities and more other non-profitable activities. Banks are bound to perform these activities due to the accountability of the central bank while for the Shariah activities management, and all of us are liable to Almighty Allah, where we are not concerned regarding this". [SP\#6]

Nonetheless, Islamic banks are not worried about disclosing the Shariah non-compliance amount because it would tarnish the institutional image, fund collections, and public confidence. Therefore, it is very important for all corporations working in Islamic finance environment to give more attention for disclosure about its financial statement and reports to the equity holders to mitigate the conflict of interest's issues, agency problems and to achieve reasonable control of the firm (Mosab, 2019) "Islamic banks also are not interested because the rating will minimize, and they will be sufferer, and public confidence will minimize; as a result, they are not taking this risk." [SP\#7]

Every Islamic bank sets up the research and development section, but no research in terms of SG, publications, and journals is carried out. Though IBBL has a 'Scopus' journal entitled "Journal of Islamic Economics, Banking and Finance," it has not been published, and BOD has dissolved the editorial board. The Central Shariah Board for Islamic Banks of Bangladesh (CSBIB) has also released a few newsletters, bulletins, and books but for the last 4 or 5 years, there were no initiatives from CSBIB to produce any publications though they have one journal. As a result, SSB, Islamic banks, and regulators do not know the actual problems of SG. What should be solved, and how can they overcome the challenges?

Moreover, there are no suggestions to solve these problems. On the other hand, there are no conferences, seminars, and symposiums regarding SG and its issues. Generally, there is no active research concerning SG though there are research and development departments.

"I want to say so many lacking, and that is research. Research is a tremendous lacking, and I can consider there is no research in Bangladesh in this field, in the field of $S G$. As per I know, the CSBIB has tried to publish few newsletters, bulletin, or one or two books but the last 4/5 years we did not see any proceedings or progress and some Islamic banks only for their resolutions which is prepared or decided in the SSB meeting they have published, but as a research project, there is no effort at all Bangladesh. Second, there is no seminar symposium, conference, and in this regard, the research and development department of the Islamic banks are not including the Shariah. But the Islamic banks commonly say that the research and development department exists, but this matter is not that way". [SP\#7]

Bangladesh does not have separate and independent Shariah rating agencies and Islamic Chartered Accountant firms; thus, Islamic banks are getting more privileges. The regulators and public cannot detect Shariah violations because, in the annual report, SSBs claim that they follow 100 percent Shariah principles, but in reality, Shariah guidelines never got a mention at all. Moreover, Islamic banks are not interested in Shariah rating agencies to safeguard their image, issues, public confidence, and other business losses.

"There is no independent Shariah rating agency in 
Bangladesh; as a result, all the Islamic banks are getting a wider facility that nobody can say against themselves because of their Shariah rating as it 100 percent okay. Sometimes you know all banks are not rating in the same, $I B B L$ also. Because how much the violation the rating will minimize". [SP\#7] "Islamic banks also are not interested because the rating will minimize, and they will be sufferer, public confidence will minimize; as a result, they are not taking this risk." [SP\#7]

In the current situation, SG structure of Bangladesh according to the respondents from Shariah background and experts from their experience (E\#3; SP\#1, 2, 4, 5, 6) Bangladesh has the shortage of experienced, knowledgeable and qualified executives, policymaker, bankers, SSB and Shariah executive officers. These are mainly due to the absence of the Islamic banking act, regulatory, and government supports. Moreover, there are no bindings from the central bank in accomplishing Islamic banking.

"There is a lack of Shariah, knowledgeable people." [SP\#4] "We do not have enough Shariah knowledgeable bankers to serve also." [SP\#5] "But in our country Shariah secretariat department, the manpower is not educated, and the experts have desired are not sometimes there." [E\#3] "There is an absence of experienced people, banker and policymaker in this sector due to the lack of Islamic products, Islamic banking support, central bank support, and government support. Problems are that there are no obstacles from the government". [SP\#2]

The regulatory respondents also outline the limitation faced by the central bank as well as skilled and knowledgeable Shariah personnel and the mechanisms in monitoring, guiding, and supervising the Islamic banks.

Moreover, most of the executives are not sincere with SG and Islamic banking due to some negative issues such as fundamentalist, 'Jamati' (political motto), and negative view, or attitude or concept of their colleague. The researcher also observes a similar situation during data collection. The respondents are not free and willing to discuss and talk, and they are under an invisible pressure. Additionally, they are not enthusiastic and not focused on promoting Islamic banking. Thus, they are not concerned with the internal issues of Islamic banks.

"Presently at Central Bank has no instrument, only one which is not efficiently functioning now." [RA\#2] "If you consider our people here in the central bank, mostly they are ignorant about the modalities of the Islamic banking." [RA\#2] "I think the central bank does not give much attention to it. Just watches a little bit". [SP\#1]
"Bangladesh Bank is not a concern for the internal matters of the banks." [RA\#2]

Moreover, the central bank has limitations regarding Shariah audit and Shariah issues. Due to the lack of Shariah experts in the central bank, it is difficult for them to accomplish the proper Shariah audit. Moreover, they have limited knowledge regarding the function of Shariah audit functions. Therefore, they do not concentrate on Shariah issues, but rather on general matters. Thus, in accomplishing the Shariah issues, they ask Shariah auditors and management, as well as SSB, for further clarifications, which also indicate the knowledge gap of the central bank executives regarding Shariah issues.

"Especially and the auditing is a very tough matter, but they are very much ignorant about the functions of the Islamic banks." [RA\#2] "Especially central bank inspectors most of the time they do not give concentration on the Shariah issues, they go and inspect the issues, and sometimes consult with the Shariah auditors and the management of the bank, sometimes they go through the issues, Shariah issues funded out by the Shariah auditor and fixed some issues from the SSB." [RA\#3]

The existing CSBIB failed to arrange effective and efficient programs, conferences, and meeting for SSB members in all Islamic banks, though they have arranged only one meeting for all SSB members in the last ten years. Moreover, it is essential to have a CSSB and SGF under the authority of the central bank to conduct Shariah research, identify the problems, publish a journal, and increase the cooperation among SSB members. As Islamic banks already flourished and accelerated in Bangladesh, it is high time to set up a central authority for monitoring SG functions.

The above discussion states due to the absence of a comprehensive SGF, Islamic banks have developed their SG guidelines. SSBs have a lack of knowledge and limitations concerning English, which also hinders the functions of the Islamic banks. Besides, there is a lack of training for the Shariah officers and banks' executives and research about product development and services.

\section{Conclusion}

The study aimed to identify the problems faced by SSB, bankers, and regulators to bridge the gaps between them in the existing practices of SG in Bangladesh. Based on the outlined questions and identified answers, this part is overviewing the significant findings. This research finds the Islamic banks are more successful in Bangladesh 
because of public demand and religious influence. Therefore, to monitor the functions of Islamic banks, Bangladesh needs a comprehensive SGF, a separate Islamic banking act, a standard accounting system, and a robust Shariah audit system which are similar with the view of previous researchers (Sarker, 2005; Ahmad \& Hassan, 2007; Mamun, 2011; Ahmad et al., 2014; Ullah, 2014; Perves, 2015). Bangladesh has a shortage of experts, experienced, knowledgeable and qualified Shariah people, policymakers, bankers, SSB members, executives and Shariah officers due to the absence of Islamic banking act, and proper regulatory supports (Malik et al., 2011; Rahman, 2014; Hassan et al., 2017). Besides, Bangladesh does not have any Shariah audit firm, Shariah index institutions, CSSB under the central bank, and finally, the Islamic banks are not bound to assure full Shariah compliance. Therefore, due to the absence of CSGF and as a regulatory order, Islamic banks have to develop their SG guidelines and run their functions based on those guidelines and other instructions of the central bank.

Additionally, Bangladeshi higher institutions do not have any professional degrees concerning Islamic finance or $\mathrm{SG}$, and as a result, they are unable to provide the expected products and services (Abdullah \& Rahman, 2017). Frequently, the management recruits inexperienced and general background executives for the Shariah department while the experts and experienced executives of this department are in the branches. In the function of $\mathrm{SG}$, Islamic banks do not accomplish a complete audit to check all of their investments and business transactions because of the shortage of Shariah executives (Ullah, 2014). Generally, BOD, management, executives, customers, and the public also have the conceptual gap about Islamic banks, SG, and banking system compared to the regular prayers, faith, and belief. Finally, concerning Shariah issues, BOD and management are not a concern (Sarker, 2005; Ahmad et al., 2014), and they forget their responsibility and accountability towards Almighty Allah.

However, our study has significantly contributed to the existing literature of the Islamic banks concerning Bangladesh and implies the regulators, Islamic banks, BOD, SSB, and other concerned authorities. Firstly, the study outlined the problems of SG and different bodies related to its regulations and applications, which will be beneficial for the Islamic banks and regulators to solve these problems for effective monitoring and improvement of the existing practices. Besides, the central bank can update the present guideline by improving the suggestions of this research and solving these problems. The central bank should outline a general direction for the effective functioning of the Islamic banks and their SG, which will enhance the trust and confidence of the numerous stakeholders. Islamic banks can recruit more Shariah executive officers for full audit functions and monitoring the Shariah principles. Finally, Islamic banks, BOD, and management should focus on the Shariah issues and reveal the actual Shariah practices in their annual report for their concerned stakeholders.

This study is limited to within the Islamic banking industry instead of covering Islamic insurance and cooperative societies in Bangladesh. Besides, the present study did not include the field executives, which can be a potential area for discovering more practical problems in the application of Shariah guidelines. Future researchers can also investigate the issues of SG and concerned authorities in other jurisdictions such as Pakistan and Indonesia as well as the Gulf countries such as Saudi Arabia, Qatar, Jordan, Turkey, and Iran. The findings may be different in other jurisdictions; however, the results may differ in the other sectors of Bangladesh and Islamic banking sectors in other jurisdictions. Nevertheless, further research can explore the SG practices of other financial institutions and areas, such as Islamic cooperative, microfinance, insurance companies, real-estate companies, and halal industries in the context of Bangladesh, which also unexplored as they are also presently unexplored. Additionally, further studies can also execute the quantitative method to justify these findings concerning Bangladesh and other jurisdictions.

\section{References}

Abdullah, M. F., \& Rahman, A. (2017). Shari'ah governance of Islamic banks in Bangladesh issues and challenges. Journal of Islamic Economics, Banking and Finance, 13(3), 82-94.

Abu-Tapanjeh, A. M. (2009). Corporate governance from the Islamic perspective: A comparative analysis with OECD principles. Critical Perspectives on Accounting, 20(5), 556567.

Ahmad, N., \& Haron, S. (2002). Perceptions of Malaysian corporate customers towards Islamic banking products and services. International Journal of Islamic Financial Services, 3(4), 13-29.

Ahmad, A. U. F. \& Hassan, M. K. (2007). Regulation and performance of Islamic banking in Bangladesh. Thunderbird International Business Review, 49(2), 251-277.

Ahmad, A. U. F., Rashid, M., \& Shahed, A. K. M. (2014). Perception of bankers and customers towards deposit and investment mechanisms of Islamic and conventional banking: Empirical evidence from Bangladesh. Journal of Islamic Business and Management, 4(2), 91-114.

Ahmad, K. (2000). Islamic finance and banking: The challenge and prospects. Review of Islamic Economics, 9(1), 57-82.

Ahmed, M., \& Khatun, M. (2013). The compliance with Shariah governance system of AAOIFI: A study on Islamic banks Bangladesh introduction. Journal of Islamic Economics, Banking and Finance, 9(3), 177-191.

Akbar, S., Zulfiqar Ali Shah, S., \& Kalmadi, S. (2012). An 
investigation of user perceptions of Islamic banking practices in the United Kingdom. International Journal of Islamic and Middle Eastern Finance and Management, 5(4), 353-370.

Alam, M. K., Rahman, S. A., Mustafa, H., Shah, S. M., \& Hossain, M. S. (2019a). Shariah governance framework of Islamic banks in Bangladesh: Practices, problems and recommendations. Asian Economic and Financial Review, 9(1), 118-132. DOI: 10.18488/journal.aefr.2019.91.118.132

Alam, M. K., Rahman, S. A., Hossain, M. S., \& Hosen, S. (2019b). Shariah governance practices and regulatory problems of Islamic insurance companies in Bangladesh. International Journal of Academic Research in Business and Social Sciences, 9(1), 109-124. http://dx.doi.org/10.6007/IJARBSS/v9-i1/5368.

Alam, M. K., Tabash, M. I., Thakur, O. A., Sahabuddin, M., Hosen, S., \& Hassan, M. F. (2020a). A central Shariah regulatory authority for the Islamic banks in Bangladesh: Legalization or formation. Journal of Asian Finance, Economics and Business, $\quad 7(1), \quad$ 91-100. https://doi.org/10.13106/jafeb.2020.vol7.no1.91

Alam, M. K., Miah, M. S, Siddiquii, N., Hossain, M. I. (2020b). The Influences of board of directors and management in shariah governance guidelines of the Islamic banks in Bangladesh. Journal of Islamic Accounting and Business Research. (Forthcoming). DOI: 10.1108/JIABR-08-20190155

Alamgir, M. (2016). An Analysis of Islamic Banking Activities in Bangladesh: Issues and Challenges. Thoughts on Economics, 25(3-4), 29-58.

Archer, S. \& Karim, R. A. A. (2002). Islamic finance innovation and growth. London, UK: Euro-Money Books and AAOIFI.

Bangladesh Bank. (2009). Guideline for conducting Islamic banking. Dhaka, Bangladesh: Bangladesh Bank. Retrieved from

https://www.bb.org.bd/aboutus/regulationguideline/islamic banking/Islamic guide. php.

Bangladesh Bank. (2019). Developments of Islamic Banking in Bangladesh. Dhaka, Bangladesh: Bangladesh Bank.

Berg, B. L., \& Lune, H. (2007). Qualitative research methods for the social sciences. Boston, MA: Pearson Education.

Bryman, A., \& Bell, E. (2003). Business research methods. New York, NY: Oxford University Press.

Chapra, M. U., \& Ahmed, H. (2002). Corporate governance in Islamic financial institutions. Jeddah, Saudi Arabia: Islamic Development Bank, Islamic Research and Training Institute.

Cooper, R. D., \& Schindler, S. P. (2011). Business research methods $\left(11^{\text {th }}\right.$ ed.). Singapore: McGraw-Hill/Irwin.

Dane, F. C. (1990). Research methods. Belmont, CA: Brooks/Cole Publishing.

Dawood, M. (2008). Ensuring the quality of Syariah Advice. Middle East Foreign Exchange (MEFX). Dubai, UAE: Dubai Financial Center.

Garas, S. N., \& Pierce, C. (2010). Shari'a supervision of Islamic financial institutions. Journal of Financial Regulation and Compliance, 18(4), 386-407.

Ghayad, R. (2008). Corporate governance and the global performance of Islamic banks. Humanomics, 24(3), 207-216.

Gibbs, G. (2002). Qualitative data analysis: explorations with NVivo. Open University, Buckingham
Gillham, B. (2000). Developing a questionnaire. London, UK: Continuum.

Ginena, K., \& Hamid, A. (2015). Foundations of Shari'ah governance of Islamic banks. London, UK: John Wiley \& Sons.

Grais, W., \& Pellegrini, M. (2006). Corporate governance and stakeholders' financial interests in institutions offering Islamic financial services (World Bank Policy Research Working Paper No. 4054). Washington, DC: World Bank.

Hassan, M. K., Ullah, M. H., \& Khanam, R. (2017). Shariah governance practices in Bangladesh. In A. Nazim (ed.), Shariah governance systems and practices in a globalized world. $\quad$ Retrieved from https://www.researchgate.net/publication/322077917_Shari\% 27ah_Governance_Practices_in_Bangladesh

Khan, M. S. \& Mirakhor, A. (1986). The framework and practice of Islamic banking. Finance and Development, 23(3), 32-41.

IFSB (2009). Guiding principles on Shari'ah governance systems for institutions offering Islamic financial services. Kuala Lumpur, Malaysia: Islamic Financial Services Board.

Imam, P., \& Kpodar, K. (2013). Islamic banking: How has it expanded?. Emerging Markets Finance and Trade,49(6), 112-137.

Jalil, A. \& Rahman, M. K. (2010). Financial transactions in Islamic Banking are viable alternatives to the conventional banking transactions. International Journal of Business and Social Science, 1(3) 219-233.

Joffe, H., \& Yardley, L. (2004). Content and thematic analysis. Research methods for clinical and health psychology. Thousand Oaks, CA: Sage Publications.

Kvale, S. (1996). Interviews: An introduction to qualitative research interviewing. Thousand Oaks, CA: Sage Publications.

Laldin, M. (2008). Roles and responsibilities of Shari'ah scholars in Shari'ah advisory services seriespart 1 of 2. The Halal Journal, 11(5), 54-56

Malik, M. S., Malik, A., \& Mustafa, W. (2011). Controversies that make Islamic banking controversial: An analysis of issues and challenges. American Journal of Social and Management Sciences, 2(1), 41-46.

Mamun, M. Z. (2011). Prospects and problems of Islamic banking from bank's perspective: A study of Bangladesh. Paper presented at the 8th International Conference on Islamic Economics and Finance, Doha, Qatar. (June), 1-21.

Mosab, I. T. (2019). An Empirical Investigation on the Relation between Disclosure and Financial Performance of Islamic Banks in the United Arab Emirates. Journal of Asian Finance, Economics and Business, 6(4), 2735. https://doi.org/10.13106/jafeb.2019.vol6.no4.27

Mouton, J. (2001). How to succeed in your Master's and Doctoral Studies: A South Africanguide and resource book. Pretoria, South Africa: Van Schaick Publishers.

Myers, M. D. (2009). Qualitative research in business and management. London, UK: Sage.

Naser, K., Jamal, A. \& Al-Khatib, K. (1999). Islamic banking: a study of customer satisfaction and preferences in Jordan. International Journal of Bank Marketing, 17(3), 135-151.

Noman, A. H., Pervin, S., Chowdhury, N. J., Hossain, A., \& Banna, H. (2017). Comparative performance analysis between conventional and Islamic banks in Bangladesh- An 
Application of Binary Logistic Regression. Asian Social Science, 11(21), 248-257. https://doi.org/10.5539/ass.v11n21p248

Patton, M. Q. (2002). Qualitative research and evaluation methods (3rd ed.). Thousand Oaks, CA: Sage Publications.

Perves, M. M. (2015). Legal and regulatory framework in Islamic banking system: Bangladesh perspective. European Journal of Business and Management, 7(21), 179-188.

Rahman, A. R. A., (2007). Islamic banking and finance: Between ideals and realities. International Journal of Economics, Management and Accounting, 15(2), 197-217.

Rahman, J. M. (2014). Cost-Benefit analysis of implementing Shari'ah auditing as a separate discipline in Bangladeshi Islamic banks (pp. 1-18). Retrieved November 10, 2019 from http://ssrn.com/abstract $=2538590$ http://dx.doi.org/10.2139/ssrn.2538590.

Rammal, H. G. (2006). The importance of Shari'ah supervision in Islamic financial institutions. Corporate Ownership and Control, 3(3), 204-208.

Rashid, M., Hassan, M. K., \& Ahmad, A. U. F. (2009). Quality perception of the customers towards domestic Islamic banks in Bangladesh. Journal of Islamic Economics, Banking and Finance, 5(1), 109-131.

Sarker, A. A. (1998). Islamic banking in Bangladesh: Growth, structure and performance (Unpublished master's thesis). Loughborough University, UK.

Sarker, A. A. (2005). Islamic banking in Bangladesh: Achievements and challenges. Journal of Islamic Economics, Banking and Finance, 1(1), 45-59.

Saunders, M., Lewis, P., \& Thornhill, A. (2007). Research Methods for Business Students. Hemel Hempstead, England: Prentice-Hall.

Sekaran, U. (2003). Research methods for business: A skill building approach. Hoboken, NJ : John Wiley \& Sons. (pp. 218-261).

Sekaran, U., \& Bougie, R. (2010). Research methods for business: A skill building approach. Hoboken, NJ : Wiley.

Siddiqi, M. N. (1983). Issues in Islamic banking. Leicester, UK:
The Islamic Foundation.

Siddiqui, S. H. (2001). Islamic banking: True modes of financing. New Horizon, 109(2), 15-20.

Stake, R. E. (2005). Qualitative case studies. In N. K. Denzin \& Y S. Lincoln (Eds.), The Sage handbook of qualitative research (pp. 443-466). Thousand Oaks, CA: Sage Publications.

Strauss, A. L. (1987). Qualitative analysis for social scientists. Cambridge, UK: Cambridge University Press.

Tomkins, C., \& Karim, R. A. A. (1987). The Shari'ah and Its Implications for Islamic Financial Analysis: An Opportunity to Study Interactions Among Society, Organizations, and Accounting. American Journal of Islamic Social Sciences, 4(1), 101-113

Ullah, M. H. (2014). Shari'ah compliance in Islamic banking - An empirical study on selected Islamic banks in Bangladesh. International Journal of Islamic and Middle Eastern Finance and Management, 7(2), 182-199. https://doi.org/10.1108/IMEFM-06-2012-0051

Ullah, M. H., \& Khanam, R. (2018). Whether Shari'ah compliance efficiency a matter for the financial performance: The case of Islami Bank Bangladesh Limited. Journal of Islamic Accounting and Business Research, 9(2), 183-200.

Ullah, M. H., Khanam, R., \& Tasnim, T. (2018). Comparative compliance status of AAOIFI and IFSB standards: An empirical evidence from Islami Bank Bangladesh Limited. Journal of Islamic Accounting and Business Research, 9(4), 607-628.

Wasiuzzaman, S., \& Gunasegavan, N. U. (2013). Comparative study of the performance of Islamic and conventional banks: The case of Malaysia. Humanomics, 29(1), 43-60.

Warde, I. (2013). Islamic finance in the global economy. Dubai, UAE: CFA Institute Middle East Investment Conference.

Wilson, R. (2010). Introduction in Islamic finance innovation and authenticity. In N. Ali (ed.), Islamic finance project. Cambridge, MA: Harvard Law School.

Yin, R. K. (2003). Case study research: Design and methods. Thousand Oaks, CA: Sage Publishing. 